Proceedings

\title{
Nanoparticles loading essential oils as alternative solution for the postharvest control of the date moth Ectomyelois ceratoniae (Pyralidae) ${ }^{\dagger}$
}

\author{
Maha Ben Abada 1, 2, Maroua Tahri 2, Sophie Fourmentin ${ }^{3}$ and Jouda Mediouni Ben Jemâa 2, * \\ 1 University of Carthage, National Agronomic Institute of Tunisia (INAT), City Mahrajene, Tunis, Tunisia; \\ mahabenabada@gmail.com \\ 2 University of Carthage, National Agricultural Research Institute of Tunisia (INRAT), Laboratory of Bio- \\ technology Applied to Agriculture LR11INRAT06, Tunis, Tunisia; tahrymaroua@gmail.com \\ 3 Unité de Chimie Environnementale et Interactions sur le Vivant (UCEIV, EA 4492), SFR Condorcet FR CNRS \\ 3417, ULCO, F-59140 Dunkerque, France; lamotte@univ-littoral.fr \\ * Correspondence: joudamediouni1969@gmail.com; Tel.: +21697652174 \\ + Presented at the 1st International Electronic Conference on Entomology (IECE 2021), 1-15 July 2021; \\ Available online: https://iece.sciforum.net/.
}

Citation: Ben Abada, M.; Tahri, M.; Fourmentin, S; Mediouni-Ben Jemâa, J. Nanoparticles loading essential oils as alternative solution for the postharvest control of the date moth Ectomyelois ceratoniae (Pyralidae), in Proceedings of the 1st International Electronic Conference on Entomology, 1-15 July 2021, MDPI: Basel, Switzerland, doi:10.3390/IECE-10394

Published: 30 June 2021

Publisher's Note: MDPI stays neutral with regard to jurisdictional claims in published maps and institutional affiliations.

Copyright: (C) 2021 by the authors. Submitted for possible open access publication under the terms and conditions of the Creative Commons Attribution (CC BY) license

(http://creativecommons.org/licen ses/by/4.0/).

\begin{abstract}
Ectomyelois ceratoniae (Pyralidae) is the main insect pest attacking dates in field and storage in Tunisia. Postharvest protection is relied on fumigants. This work investigates fumigant toxicity of 2-hydroxypropyl-beta-cyclodextrin (HP- $\beta$-CD) loading Rosmarinus officinalis essential oil and its major constituents (1,8-cineole, $\alpha$-pinene, camphor, borneol) against E. ceratoniae larvae and adults. Results revealed that mortalities reached $56.86 ; 60.71 ; 64.28 ; 50$ and $75 \%$ respectively for the crude essential oil, $\alpha$-pinene, camphor, borneol and 1,8-cineole after 30 storage days at the concentration $90 \mu \mathrm{l} / 1$ air. Also, results indicated that 1,8-cineole, camphor and $\alpha$-pinene showed the strongest inhibitory effects of adults emergence.
\end{abstract}

Keywords: Ectomyelois ceratoniae; Rosmarinus officinalis; Cyclodextrin; Dates; Fumigation

\section{Introduction}

Essential oils and their compounds exhibited a variety of biological functions including insecticidal activities [1,2]. Indeed, various studies reported the potential of many plant derived essential oils against insect pests mainly those infesting stored products [3,4].

Despite the promising potential of EO, their applications are limited due to their degradation and volatilizations because of their volatile components [5]. So, the usage of controlled-release formulations could be an interesting option for the development of bioinsecticide [6]. In this respect, in last years, cyclodextrin were successfully used as enclusion matrix to encapsulate bioactive substances including essential oils' compounds [7]. Encapsulation prolongs the active compounds viability [8]; increase the compounds solubility in water [9]; and prevent from light and environmental degradation factors [10]. Rosemary (Rosmarinus officinalis L.) is native to Mediterranean region [11]. Rosemary essential oil is kwnown by its biological activities like antifungal [12], antibacterial [13], antioxidant properties [14] and insecticidal potential [15].

The present research was designed to explore the fumigant toxicity of the 2-hydroxypropyl-beta-cyclodextrin (HP- $\beta$-CD) loading $R$. officinalis essential oil or its major constituents (1,8-cineole, $\alpha$-pinene, camphor,borneol) nanoparticles against larvae and adults of the date moth Ectomyelois ceratoniae for different storage periods.

\section{Materials and Methods}




\subsection{Insect rearing.}

E. ceratoniae rearing was conducted under controlled laboratory conditions (Temperature $28 \pm 1^{\circ} \mathrm{C}$, photoperiod of $12 \mathrm{~L} / 12 \mathrm{D}, 75 \pm 5 \%$ relative humidity). Rearing was conducted according to the procedure described by [16].

\subsection{Plant materials and essential oils extraction}

Arial parts of spontaneously grown R. officinalis were collected from Korbous arboretum ( $36^{\circ} 48^{\prime} 59^{\prime \prime} \mathrm{N} 10^{\circ} 34^{\prime} 07^{\prime \prime} \mathrm{E} 401$ ) in March 2020. Samples were air-dried at room temperature for two weeks. Essential oils were obtained by hydrodistillation using a modified Clevenger-type device for $4 \mathrm{~h}$. Essential oils were dried using anhydrous sodium sulphate. Yields were calculated based on plant materials dry weight. Chromatographic analyzes were performed using an Agilent-Technologies $6890 \mathrm{~N}$ Network GC system equipped with a flame ionization detector and HP-5MS capillary column (30 $\mathrm{m \times 0.25mm}$, film thickness $0.25 \mu \mathrm{m}$; Agilent-Technologies, Little Falls, CA, USA).

\subsection{Standards and chemicals}

1,8-cineole, pinene and camphor standards were supplied from Sigma-Aldrich (purity grade).

\subsection{Encapsulation in $H P-\beta-C D$}

Excess amounts from standards (1,8-cineole, pinene, camphor, borneol ) were added to $5 \mathrm{ml} \mathrm{HP}-\beta$-CD solutions $(10,25,50,75,100 \mathrm{mM})$. Mixtures were shaken at $25^{\circ} \mathrm{C}$ for $24 \mathrm{~h}$ then filtered using a $0.45 \mu \mathrm{m}$ membrane filter. HPLC method was used to determine the oil and standards concentrations in the filtrates. Encapsulation efficiency was calculated according to the equation: EE $(\%)=\left(\mathrm{m}_{\exp } / \mathrm{mi}^{*}\right)^{*} 100$ where $\mathrm{m}_{\exp }$ is the mass of the oil or standards experimentally determined by HPLC in the inclusion complex solution and $\mathrm{m}_{\mathrm{i}}$ is the mass of the oil or standards initially used to prepare the inclusion complex.

\subsection{Fumigant toxicity bioassays}

\subsubsection{Larval mortality and adult emergence}

Larval mortality was assessed for three essential oil concentrations, respectively 30 , 60 and $90 \mu \mathrm{l} / 1$ air. For the standards, the respective used concentrations were 30; 60 and $90 \mu \mathrm{g} / \mathrm{l}$ air. For each trial, three replications were performed. $2 \mathrm{~cm}$ diameter Whatman filter papers were impregnated with the different oil concentrations. Impregnated filter paper was attached to the covers of $1 \mathrm{~L}$ glass bottle. Each bottle contained 20 unsexed larvae (placed in dates). Mortality was recorded after 7, 15, 30 and 37 days. Abbott formula [17] was used to assess the mortality.

Moths' emergence was registered daily for each trial. Percentage of emerged adults was determined by formula of Arivoli [18].

\subsubsection{Lethal concentration and Lethal time bioassays}

Probit analysis [19]) was used to determine the respective lethal concentration (LC50) and lethal Time (LT50) values for the various treatments after 15 days of exposure.

\subsubsection{Formulation insecticidal efficacy}

Same procedure was employed to evaluate the larvicidal and adulticidal effect of the formulations. For that, the solid HP- $\beta-C D / R$. officinalis and HP- $\beta-C D /$ standards inclusion complex were placed in $1 \mathrm{~L}$ glass bottles containing 20 unsexed larvae and 10 adults. Mortality data was assessed by Abbott's formula [17], adult emergence percentages were determined by Arivoli formula [18].

\subsection{Statistical analysis}

Data were subjected to analysis of variance ANOVA using SPSS software version 20 (IBM Corporation NY, USA). Duncan's test was employed to notice significant differences at the level $0.05 \%$. Values presented the means of three replications and expressed as the mean $\pm \mathrm{SD}$. 


\section{Results}

\subsection{Essential oil yield and chemical composition}

The chemical composition of R. officinalis essential oil is reported in Table 1 as percentages of chemical classes.

Table 1. Chemical classes of R. officinalis essential oil collected from arboretum of Korbous and extraction yield

\begin{tabular}{cc}
\hline Chemical classes & Proportion (\%) \\
\hline Monoterpenes hydrocarbons & 34.47 \\
Oxygenated Monoterpenes & 61.88 \\
Sesquiterpene Hydrocarbons & 2.24 \\
Others & 0.53 \\
Total of identified compounds & 99.12 \\
Extraction yield & 0.6 \\
\hline
\end{tabular}

Results showed that R. officinalis essential is dominated by Monoterpenes with respective percentages of $61.88 \%$ for oxygenated Monoterpenes and $34.47 \%$ for Monoterpenes hydrocarbons. On the other hand, extraction yield was $0.6 \%$.

\subsection{Encapsulation efficiency}

The Encapsulation Efficiency Encapsulation of the various compounds ( $\alpha$-pinene, 1,8-cineole, Camphor)r and R. officinalis essential oil in HP- $\beta-C D$ inclusion complex are presented in Table 2.

Table 2. Encapsulation Efficiency (EE\%) of $\alpha$-pinene, 1,8-cineole, Camphor and R. officinalis essential oil in HP- $\beta$-CD inclusion complex.

\begin{tabular}{cccc}
\hline$\alpha$-pinene & 1,8-cineole & Camphor & Essential oil \\
\hline 20 & 63 & 23 & 22 \\
\hline
\end{tabular}

Results indicated that the encapsulation efficiency varied among compounds and the essential oil. The highest EE value was obtained for 1,8-cineole with $63 \%$. However, $\alpha$-pinene, Camphor and the essential oil presented close respective EE values of 20, 23 and $22 \%$.

\subsection{Insecticidal toxicity}

\subsubsection{Insect mortality}

The insecticidal activities of free and encapsulated compounds and $R$. officinalis essential oil were illustrated in figure 1.

Results (Figure 1) revealed that fumigant toxicity varied between free and encapsulated compounds. For all compounds and $R$. officinalis essential oil, toxicity was greater in the case of free compared to encapsulation. Moreover, results indicated that toxicity increased for encapsulated compounds over exposure periods. 


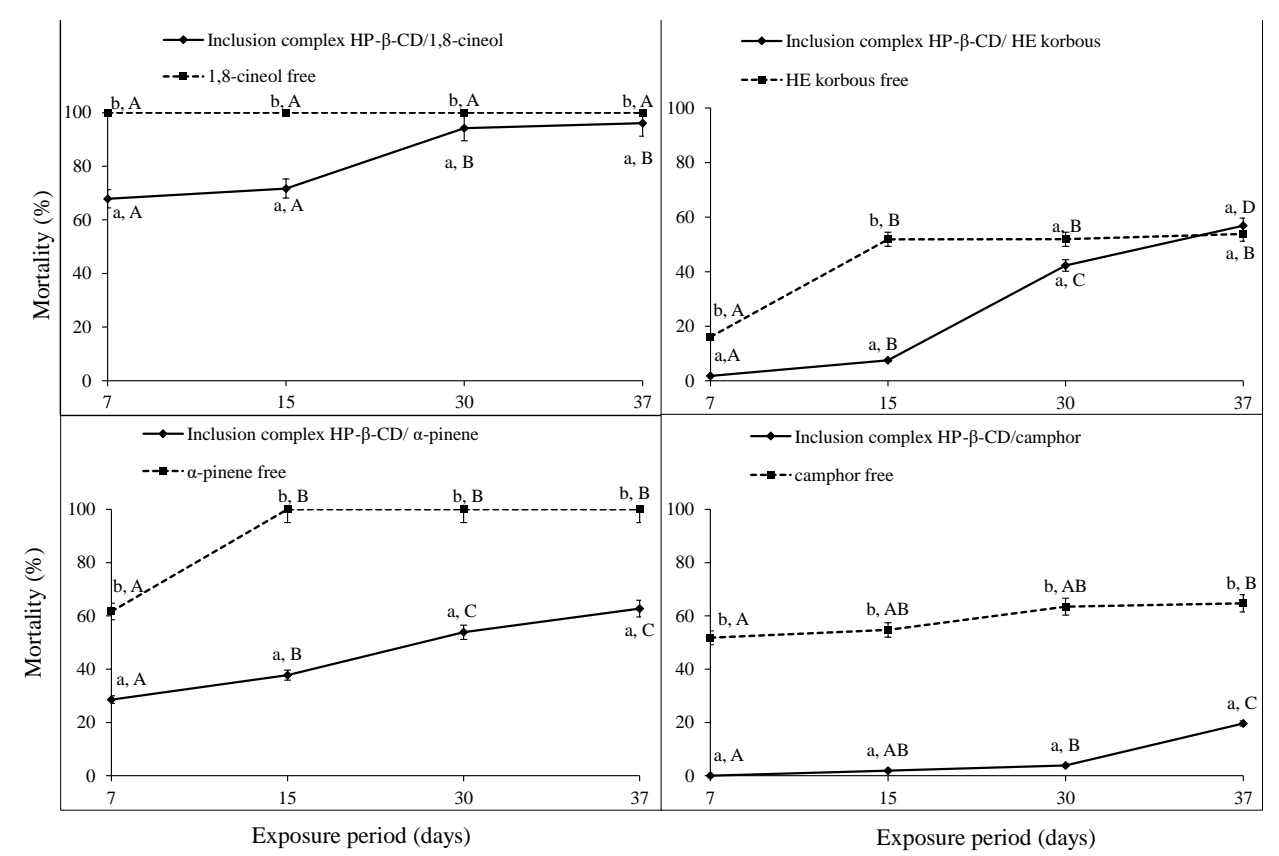

Figure 1. Mortalities (\%) of fifth instar larvae of Ectomyelois ceratoniae exposed to free and encapsulated (HP- $\beta$-CD inclusion complex) R. officinalis essential oil and the compounds (Letters denotes significant differences at $\mathrm{P}<0.05$ in percent mortality for each exposure period (uppercase) and each concentration (lowercase); Duncan's test).

\subsubsection{Lethal concentrations}

Table 3 cited the lethal concentrations values of $R$. officinalis essential oil and the three standards determined by Probit method.

Table 3. Median Lethal Concentrations values ( $\mu 1 / 1$ air) of 1,8-cineole, $\alpha$-pinene Camphor and R. officinalis against fifth instar larvae of Ectomyelois ceratoniae

\begin{tabular}{ccccc}
\hline Compounds & 1,8-cineole & $\alpha$-pinene & Camphor & R. officinalis \\
\hline CL50 a,b & 65.13 & 97.415 & 223.764 & 160.008 \\
$(\mu \mathrm{l} / \mathrm{l}$ air $)$ & $(46.45-122.61)$ & $(63.71-146.12)$ & $(47.94-312,22)$ & $(136.46-229)$ \\
\hline
\end{tabular}

a Units $\mathrm{LC}_{50}=\mu \mathrm{m} / \mathrm{l}$ air

b 95\% lower and upper confidence limits are shown in parentheses.

Results pointed out that 1,8-cineole and $\alpha$-pinene were more toxic than $R$. officinalis and Camphor.

\subsubsection{Lethal Time}

Table 4 reported the lethal time values of $R$. officinalis essential oil and the three standards determined by Probit method.

Table 4. Median Lethal Time values (days) of 1,8-cineole, $\alpha$-pinene Camphor and R. officinalis against fifth instar larvae of Ectomyelois ceratoniae

\begin{tabular}{ccccc}
\hline Compounds & 1,8-cineole & $\alpha$-pinene & Camphor & R. officinalis \\
\hline \multirow{2}{*}{ LT $_{50}$ a,b (days) } & 23.918 & 29 & 22.958 & 35.806 \\
& $(18.12-33.48)$ & $(17.86-48.69)$ & $(15.41-68.74)$ & $(27.233-64.88)$ \\
\hline
\end{tabular}

a Units LT $\mathrm{LT}_{50}$ days

b 95\% lower and upper confidence limits are shown in parentheses.

Results revealed that lethal time values varied among compounds and essential oil. 1,8-cineole and Camphor were more toxic compared to $\alpha$-pinene and $R$. officinalis essential oil.

\section{Discussion}

The postharvest control of E. ceratoniae is mainly based on the use of synthetic fumigants [20]. Recently, the use of essential oils has gained attention as pest management agents, due to their insecticidal proprieties [21]. 
This work indicated the insecticidal potential of R. officinalis essential oil in controlling the date moth E. ceratoniae. Our results are consistent with those found by [6]. Moreover, [22] pointed out that LC50 values varied between 14.02 and $171.11 \mu \mathrm{l} / 1$ air. Besides, [23] reported that for E. ceratoniae, TL50 values ranged from 39.50 to $18.27 \mathrm{~h}$. On the other hand, this work showed the ability of HP- $\beta-C D$ to encapsulate and solubilize guests ( $R$. officinalis essential oil, 1,8-cineole, $\alpha$-pinene and camphor) [24,25].

This section is not mandatory but may be added if there are patents resulting from the work reported in this manuscript.

This study pointed out that encapsulated oils could be combined with existing techniques in an integrated pest management strategy for the management of stored dates' pests.

Author Contributions: MAHA BEN ABADA Conceptualization, methodology, writing-original draft preparation, software, data curation, writing-review and editing; MAROUA TAHRI resources, data curation; formal analysis; resources; SOPHIE FOURMENTIN Conceptualization, validation, supervision, project administration, review and editing; JOUDA MEDIOUNI-BEN JEMÂA Conceptualization, validation, supervision, project administration, review and editing. All authors have read and agreed to the published version of the manuscript.

Funding: "This research was funded by the "PHC Utique" program of the French Ministry of Foreign Affairs and Ministry of higher education, research and innovation and the Tunisian Ministry of higher education and scientific research in the CMCU project number 20G0904".

Informed Consent Statement: Not applicable

Data Availability Statement: Data available in a publicly accessible repository.

Acknowledgments: Authors thank Ms. Emna BOUSHIH for her technical support in the laboratory experiments.

Conflicts of Interest: "The authors declare no conflict of interest". 


\section{References}

1. Hammoud, Z.; Gharib, R.; Fourmentin, S.; Elaissari, A., Greige-Gerges, H. Drug-in-hydroxypropyl- $\beta$-cyclodextrin-in-lipoid S100/cholesterol liposomes: Effect of the characteristics of essential oil components on their encapsulation and release. Int. J. Pharm 2020, 579, 119-151. https://doi.org/10.1016/j.ijpharm.2020.119151

2. Mediouni-Ben Jemâa, J. Essential oil as a source of bioactive constituents for the control of insect pests of economic importance in Tunisia. Med Aromatic Plants 2014, 3, 1-7. http://dx.doi.org/10.4172/2167-0412.1000158

3. Titouhi, F.; Amri, M.; Messaoud, C.; Haouel, S.; Youssfi, S.; Cherif, A.; Mediouni Ben Jemâa, J. Protective effects of three Artemisia essential oils against Callosobruchus maculatus and Bruchus rufimanus (Coleoptera: Chrysomelidae) and the extended side-effects on their natural enemies. J. Stored. Prod. Res. 2017, 72, 11-20. https://doi.org/10.1016/j.jspr.2017.02.007

4. Management of three pests' population strains from Tunisia and Algeria using Eucalyptus essential oils

5. Haouel Hamdi, S.; Hedjal-Chebheb, M., Kellouche, A.; Khouja, M.L.; Boudabous, A.; Mediouni Ben Jemâa , J. Ind. Crops. Prod. 2015, 74, 551-556. https://doi.org/10.1016/j.indcrop.2015.05.072

6. Borges, D.F.; Lopes, E.A.; Fialho Moraes, A.R.; Soares, M.S.; Visôtto, L.E.; Oliveira, C. R.; Moreira Valente, V.M. Formulation of botanicals for the control of plant-pathogens: A review. Crop. Prot. 2018, 110, 135-140. https://doi.org/10.1016/j.cropro.2018.04.003

7. Ben Abada, M.; Haouel Hamdi, S.; Gharib,R.; Messaoud, C.; Fourmentin, S.; Hélène Greige-Gerges, H.; Mediouni Ben Jemâa, J. Post-harvest management control of Ectomyelois ceratoniae (Zeller) (Lepidoptera: Pyralidae): new insights through essential oil encapsulation in cyclodextrin. Pest Manag Sci 2019, 75, 2000-2008. https://doi.org/10.1002/ps.5315

8. Estrada-Cano, C.; Castro, M.A.A.; Muñoz-Castellanos, L.N.A.O.A.; García-Triana, N.A.O.A.; Hernández-Ochoa, L.. Antifungal activity of microcapsulated clove (Eugenia caryophyllata) and Mexican oregano (Lippia berlandieri) essential oils against Fusarium oxysporum. J. Microb. Biochem. Technol. 2017, 9, 567-571. http://doi.org/10.4172/1948-5948.1000342.

9. Li, X.; Wu, Z.; He, Y.; Ye, B.C.; Wang, J. Preparation and characterization of monodisperse microcapsules with alginate and bentonite via external gelation technique encapsulating Pseudomonas putida Rs-198. J. Biomater. Sci. Polym 2017, 28, 15561571. http://doi.org/10.1080/09205063.2017.1335075.

10. Sherje, A.P.; Kulkarni, V.; Murahari, M.; Nayak, U.Y.; Bhat, P.; Suvarna, V.; Dravyakar, B. Inclusion complexation of etodolac with hydroxypropyl-beta-cyclodextrin and auxiliary agents: formulation characterization and molecular modeling studies. Mol. Pharm 2017, 14, 1231-1242. http://doi.org/10.1021/acs.molpharmaceut.6b01115

11. Abas Shah, M.; Wani, S.; Ali Khan, A.. Nanotechnology and insecticidal formulations. J. Food. Bioeng Nanoproc 2016, 3, 285-310.

12. Begum, A.; Sandhya, S.; Ali, S.S.; Vinod, K.R.; Reddy, S.; Banji, D. 2013. An in-depth review on the medicinal flora Rosmarinus officinalis (Lamiaceae). Acta Sci. Pol. Technol. Aliment. 2013, 12, 61-73.

13. Özcan, M.M.; Chalchat, J.C. Chemical composition and antifungal activity of rosemary (Rosmarinus officinalis L.) oil from Turkey. Int.J.Food Sci. Nutr. 2008, 59, 691-698. http://doi.org/ 10.1080/09637480701777944.

14. Fu, Y.; Zu, Y.; Chen, L.; Shi, X.; Wang, Z.; Sun, S.; Efferth, T. Antimicrobial activity of clove and rosemary essential oils alone and in combination. Phytotherapy Research 2007, 21, 989-994. http://doi.org/ 10.1002/ptr.2179

15. Hendel, N.; Larous, L.; Belbey, L. Antioxidant activity of rosemary (Rosmarinus officinalis L.) and its in vitro inhibitory effect on Penicillium digitatum. Int. Food Res. J. 2016, 23, 1725.

16. Amri, I.; Hamrouni, L.; Hanana, M.; Jamoussi, B.; Lebdi, K. Essential oils as biological alternatives to protect date palm (Phoenix dactylifera L.) against Ectomyelois ceratoniae Zeller (Lepidoptera: Pyralidae). Chil.J. Agric. Res 2014, 74, $273-279$. http://dx.doi.org/10.4067/S0718-58392014000300004.

17. Mediouni, J.; Dhouibi M,H. Mass-rearing and field performance of irradiated carobmoth Ectomyelois ceratoniae in Tunisia, in Area-Wide Control of Insect Pests. Springer, Dordrecht, 2007, 265-273

18. Abbott, W. A method of computing the effectiveness of an insecticide. J.Econ. Entomol 1925, 18, $265-267$.

19. Arivoli, S.; Tennyson, S.; Martin, J.J. 2011. Larvicidal efficacy of Vernonia cinerea (L.) (Asteraceae) leaf extracts against the filarial vector Culex quinquefasciatus Say (Diptera: Culicidae). J. Biopestic 2011, 4, 37-42.

20. Finney, D. Statistical logic in themonitoring of reactions to therapeutic drugs. Methods Inf Med 1971, 10,237-245.

21. Zare, Z.; Sohrabpour, M.; Fazeli, T.; Kohan, K. Evaluation of invertase (B-fructo furanosidase) activity in irradiated Mazafaty dates during storage. Radiat Phys Chem 2002, 65, 289-291. http://dx.doi.org/10.1016/S0969-806X(01)00684-3

22. Mediouni Ben Jemâa, J.; Haouel, S.; Khouja, ML. Efficacy of eucalyptus essential oils fumigant control against Ectomyelois ceratoniae (Lepidoptera: Pyralidae) under various space occupation conditions. J Stored Prod Res $2013,53,67-71$. https://doi.org/10.1016/j.jspr.2013.02.007 
23. Ben Abada, M.; Haouel Hamdi, S.; Masseoud, C.; Jroudd, H.; Bousshih, E; . Mediouni Ben Jemâa, J. Variations in chemotypes patterns of Tunisian Rosmarinus officinalis essential oils and applications for controlling the date moth Ectomyelois ceratoniae (Pyralidae). S. Afr.J.Bot 2020, 128, 18-27. https://doi.org/10.1016/j.sajb.2019.10.010

24. Haouel, S., Mediouni-Ben Jemâa, J., Boushih, E., and Khouja, M.L. Postharvest control of the date moth Ectomyelois ceratoniae using Eucalyptus essential oil fumigation. Tunis J. Plant Prot. 2010, 5, 201-212.

25. Fourmentin, S.; Ciobanu, A.; Landy, D.; Wenz, G. Space filling of $\beta$-cyclodextrin and $\beta$-cyclodextrin derivatives by volatile hydrophobic guests. Beilstein J. Org. Chem. 2013, 9, 1185-1191. https://doi.org/10.3762/bjoc.9.133.

26. Kfoury, M.; Auezova, L.; Greige-Gerges, H.; Fourmentin, S. Promising applications of cyclodextrins in food: improvement of essential oils retention, controlled release and antiradical activity. Carbohydr Polym 2015, 131, $264-272$. https://doi.org/10.1016/j.carbpol.2015.06.014 